\title{
Antimicrobial Potential of Plant Extracts from the Pitangui-Mg Region, Brazil
}

\author{
Parreira $\mathrm{AG}^{1 *}$, Azevedo EJC ${ }^{2}$, Pereira FR ${ }^{3}$, Ferreira $\mathrm{LVS}^{3}$ and Azevedo $\mathrm{RS}^{3}$ \\ ${ }^{1}$ University of the State of Minas Gerais, Divinopolis MG Unit and Federal University of Sao Joao Del Rei Campus CCO, Brazil \\ ${ }^{2}$ Department of Agricultural Research Company of Minas Gerais, Pitangui MG, Brazil \\ ${ }^{3}$ University of the State of Minas Gerais, Divinópolis MG Unit, Brazil
}

*Corresponding author: Parreira AG, University of the State of Minas Gerais, Divinopolis MG Unit and Federal University of Sao Joao Del Rei Campus CCO, Brazil.

Received Date: May 25, 2019

Published Date: June 04, 2019

\begin{abstract}
Brazil is recognized at worldwide as one of the largest holders of biodiversity on planet, possessing more than $20 \%$ of all plant species in the world, with countless of them presenting great medicinal potential. The medicinal plants use throughout the world has reached very significant economic figures, although its usage in folk medicine has been recognized for hundreds of years in different regions of the planet. The aims of this work were to evaluate the antimicrobial potential of plant extracts of Cerrado and Atlantic Forest specimens that occurs at Pitangui City region in Minas Gerais state with emphasis on those with regional folk medicine reports. The plant material used were leaves obtained from specimens collected at EPAMIG Pitangui Experimental Fields and-Technical Institute of Agriculture and Cooperatives. The extracts obtained were submitted to experiments in Petri dishes and to the diffusion disc technique to determine their antimicrobial action through the inhibition zone. For evaluation of plant extracts effects on bacterial isolates and fungal isolate growth, it was possible to see a large responses variation in a scenario of speciesspecific dependence amid the tendency of slight decrease in the Inhibitory effect for aqueous extracts. An average increase of $20 \%$ was observed in inhibition zone formation at the presence of ethanolic plant extract. For S. aureus, S. epidermidis and E. coli there was a higher number of leaf extracts in ethanolic solvent that inhibited the growth of those bacterial species, compared to the same plant extracts whose solvent was the aqueous. Exception for plant species, P. alata, in which leaf extracts only in aqueous solvent were effective against the species S. aureus and S. epidermidis. In both extracts, there was no antimicrobial effect detected for leaf extracts of B. forficata. The plant extracts that demonstrated greater amplitude of bacterial growth inhibition were. A. absinthium, S. cordifoliae, T. avellanedae, with emphasis on ethanolic extracts of these species. For fungal isolate tested, C. glabrata, there was no growth inhibition against any of plant extracts evaluated. Considering the species Baccharis retusa and Baccharis dracunculifolia, only ethanolic extracts were tested. Inhibition results were obtained for all organisms tested, except for Enterobacter cloacae in relation to ethanolic extract of B. dracunculifolia.
\end{abstract}

Keywords: Brazil medicinal plants; Bactericide potential; Bacteriostatic potential

\section{Introduction}

Brazil is recognized at worldwide as one of the largest holders of biodiversity on planet, possessing more than $20 \%$ of all plant species in the world, with countless of them presenting great medicinal potential [1]. The medicinal plants use throughout the world has reached very significant economic figures [2], although its usage in folk medicine has been recognized for hundreds of years in different regions of the planet. Thus, investment is justified in studies related to its active principles as well as new plant species with potential medicinal application, especially in Brazil, which, despite of its wide diversity of species already described, still presents large collection to be discovered and explored.
Proof of this is the enormous effort of Brazilian scientists to study the biodiversity of higher plants in the country in recent years, reflecting in the number of publications in international journals between 2011 and 2013, totaling 10000 publications in that period [3]. As another propellant factor, there is still growing interest in the use of phytotherapics and medicinal plants worldwide, especially in Brazil, where it was observed between 2013 and 2015 growth of $161 \%$ in the search for treatments based on medicinal plants and Herbal medicines by the Unified Health System (SUS), notably for treatment of Burns, gastritis and ulcers, according to data from Ministry of Health, [3]. 
Although the pharmaceutical industries have produced an expressive number of new antibiotics in recent decades, the microbial resistance to these drugs has also increased. In general, bacteria have the genetic ability to acquire and transmit resistance to drugs used as therapeutic agents (Cohen, 1992). The use of plant and phytochemical extracts of known antimicrobial activity can guarantee significant importance in various therapeutic treatments. One of several examples and most emblematic that can be cited is the case of Boldo (Peumus Boldus), very employed in Brazil for gastrointestinal discomfort treatment. In recent years, studies have shown that extracts from that plant have important antimicrobial effects, due to antimicrobial peptides presence, as well as molecules with anti-inflammatory action [4].

Several studies are routinely developed in different countries to prove their efficacy [5-10]. Fungicides originated from plants have been used for centuries. The research involving the demand for fungicide obtained from plants, however, only gained momentum in recent years. It is also noteworthy the substances diversity that exist in plants in general and possibility of finding new ones with antifungal or antibiotic action, which could be used directly by producer, through the Plant cultivation, preparation and direct application of its extracts. Another possibility refers to identification of new substances in plant extracts with fungicide and/or antibiotic characteristics which would serve as a model to chemical synthesis of their active principles in a second moment [11].

Cerrado, an important Brazilian biome, contains more than 6,000 vascular plants [12], many of them with food and medicinal value [13], however there is a very limited studies number related to species identification that present medicinal properties, to obtain extracts, biological assessments, Pharmacological and toxicological studies, which provide subsidies for their safe use, especially, when considering the great existing biodiversity. On the other hand, the Atlantic Forest, another brazilian biome, is a forest formation of most threatened in Brazil, despite its ecological importance associated with exceptional biodiversity and high endemic species rates, information about the medicinal plants potential is rare. The medicinal plants extractivism presents great potential for rational use, since it does not imply the removal of forest and compared with other uses can generate lower environmental impacts [14] (Pereira 2012). The aims of this work were to evaluate the antimicrobial potential of plant extracts of Cerrado and Atlantic Forest specimens that occurs at Pitangui City region in Minas Gerais state, with emphasis on those with regional folk medicine reports.

\section{Material and Methods}

\section{Study area}

The plant material to be used were leaves obtained from specimens collected at EPAMIG Pitangui Experimental Fields andTechnical Institute of Agriculture and Cooperatives, located at Pitangui municipality, Minas Gerais state $\left(19^{\circ} 42\right.$ ' 18.4 "latitude South and $44^{\circ} 53$ ' 10.3 "Longitude West", in Alto São Francisco region, bordering to the north by Pompéu city, to south with Conceição do Pará, to east with Jaguar of Pitangui and to east with Leandro Ferreira and Martinho Camposcities. After collects, the specimens were identified, and their specimens exsiccates were deposited at/AG herbarium from Minas Gerais State Agriculture Research Company (EPAMIG). It is important to emphasize that access to genetic heritage was registered in SISGEN with registration code A3FD8E7, in October 2018, after the institutional register completion at State University of Minas Gerais on that platform also in October 2018.

\section{Preparation and partitioning of the plant extract}

To obtain aqueous extract from leaves, the infusion method was used, in which the dried leaves are placed in hot water $(\mathrm{T}>90 \mathrm{oC})$ (DIAS et al. 2000), in a mixture of $1 \mathrm{~g}$ plant material for each 10 $\mathrm{mL}$ of water. The Maceration method was used to obtain ethanolic extract, in proportion of $1 \mathrm{~g}$ material to $9 \mathrm{~mL}$ of alcohol at $70 \%$ $(V / V)$. The next step involved the dilution of macerated material in water and DMSO (dimethyl sulfoxide) in proportion of 10:1 (Araújo et al. 2013).

\section{Antimicrobial and antifungal activity tests}

For the evaluation of bacteriostatic, bactericidal, fungicidal or fungicidal effects, the extracts obtained were submitted to experiments in Petri dishes and to the diffusion disc technique to determine their antimicrobial action through the inhibition halo. Experimental procedures will follow those described in CLSI [13].

\section{Result}

For evaluation of plant extracts effects on bacterial isolates and fungal isolate growth, it was possible to see a large responses variation in a scenario of species-specific dependence amid the tendency of slight decrease in the Inhibitory effect for aqueous extracts (table 1). An average increase of $20 \%$ was observed in inhibition halo formation at the presence of ethanolic plant extract. For S. aureus, S. epidermidis and E. coli there was a higher number of leaf extracts in ethanolic solvent that inhibited the growth of those bacterial species, compared to the same plant extracts whose solvent was the aqueous. Exception for plant species, P. alata Dryander, in which leaf extracts only in aqueous solvent were effective against the species S. aureus and S. epidermidis. In both extracts, there was no antimicrobial effect detected for leaf extracts of B. forficata. The plant extracts that demonstrated greater amplitude of bacterial growth inhibition were. absinthium, S. cordifoliae, T. avellanedae, with emphasis on ethanolic extracts of these species. For fungal isolate tested, C. glabrata, there was no growth inhibition against any of plant extracts evaluated (data not shown). Considering the species Baccharis refuse and Baccharis dracunculifolia, only ethanolic extracts were tested. Inhibition results were obtained for all organisms tested, except for Enterobacter cloacae in relation to ethanolic extract of B. Dracunculifolia. The positive and negative controls achieved the expected results by serving as a comparison parameter to treatments (data not shown) (Table $1 \& 2$ ). 
Table 1: Microbial growth inhibition results table in relation to aqueous and ethanolic leaf plant extracts 1. Chaptalia I. nutans (Arnica); 2. Passiflora alata Dryander (sweet passion fruit); 3. Artemisia absinthium L. (Losna); 4. Sida cordifolia L. (Malva); 5. Tabebuia avellanedae Lorentz ex Griseb (Ipêroxo); 6. Bauhinia forficata Link (cow shank); 7. Bidens sp.; 8. Baccharis retusa; 9. Baccharis dracunculifolia(alecrim do campo).

\begin{tabular}{|c|c|c|c|c|c|c|c|c|c|}
\hline \multicolumn{10}{|c|}{ Aqueous Vegetable extract } \\
\hline Microrganism & \multicolumn{9}{|c|}{ Zone of Inhibition } \\
\hline \multirow{2}{*}{ Staphylococcus aureus } & 1 & 2 & 3 & 4 & 5 & 6 & 7 & 8 & 9 \\
\hline & & yes & Yes & & & & & & \\
\hline \multirow{2}{*}{$\begin{array}{l}\text { Staphylococcus } \\
\text { epidermidis }\end{array}$} & 1 & 2 & 3 & 4 & 5 & 6 & 7 & 8 & 9 \\
\hline & & yes & yes & & & & & & \\
\hline \multirow{2}{*}{ Proteus mirabilis } & 1 & 2 & 3 & 4 & 5 & 6 & 7 & 8 & 9 \\
\hline & yes & & & yes & & & & & \\
\hline \multirow{2}{*}{ Enterobacter cloacae } & 1 & 2 & 3 & 4 & 5 & 6 & 7 & 8 & 9 \\
\hline & & & & yes & & & yes & & \\
\hline \multirow{2}{*}{ Escherichia Coli } & 1 & 2 & 3 & 4 & 5 & 6 & 7 & 8 & 9 \\
\hline & yes & & & & yes & & & & \\
\hline \multicolumn{10}{|c|}{ Ethanolic Vegetable extract } \\
\hline \multirow{2}{*}{ Staphylococcus aureus } & 1 & 2 & 3 & 4 & 5 & 6 & 7 & 8 & 9 \\
\hline & yes & & Yes & Yes & Yes & & & Yes & Yes \\
\hline \multirow{2}{*}{$\begin{array}{c}\text { Staphylococcus } \\
\text { epidermidis }\end{array}$} & 1 & 2 & 3 & 4 & 5 & 6 & 7 & 8 & 9 \\
\hline & & & yes & yes & yes & & & & \\
\hline \multirow{2}{*}{ Proteus mirabilis } & 1 & 2 & 3 & 4 & 5 & 6 & 7 & 8 & 9 \\
\hline & yes & & & & & & & & \\
\hline \multirow{2}{*}{ Enterobacter cloacae } & 1 & 2 & 3 & 4 & 5 & 6 & 7 & 8 & 9 \\
\hline & & & & & & & yes & yes & \\
\hline \multirow{2}{*}{ Escherichia Coli } & 1 & 2 & 3 & 4 & 5 & 6 & 7 & 8 & 9 \\
\hline & yes & & yes & yes & yes & & & yes & yes \\
\hline Klebsiella oxytoca & 1 & 2 & 3 & 4 & 5 & 6 & 7 & 8 & 9 \\
\hline
\end{tabular}

Table 2: Microbial growth inhibition results table in relation to ethanolic leaf plant extracts 1. Hyptidendrom canum (flower); 2. Hyptidendrom canum (sheets); 3. Stryphnodendron sp; 4. Xylopia sp; 5. Gochnatia sp; 6. Braccharis sp.

\begin{tabular}{|c|c|c|c|c|c|c|}
\hline \multicolumn{7}{|c|}{ Ethanolic Vegetable extract } \\
\hline Microorganism & \multicolumn{7}{|c|}{ Zone of Inhibition } \\
\hline \multirow{2}{*}{ Enterobacter cloacae } & 1 & 2 & 3 & 4 & 5 & 6 \\
\cline { 2 - 8 } & & & & & & \\
\hline \multirow{2}{*}{ Staphylococcus aureus } & 1 & 2 & 3 & 4 & 5 & 6 \\
\cline { 2 - 8 } & 1 & 2 & 3 & 4 & 5 & 6 \\
\hline \multirow{2}{*}{\begin{tabular}{c} 
Klebsiella oxytoca \\
\cline { 2 - 8 }
\end{tabular}} & 1 & 2 & 3 & 4 & 5 & 6 \\
\hline $\begin{array}{c}\text { Staphylococcus } \\
\text { epidermidis }\end{array}$ & 1 & 2 & 3 & 4 & 5 & 6 \\
\hline \multirow{2}{*}{$\begin{array}{c}\text { Acinetobacter } \\
\text { haemolyticus }\end{array}$} & 1 & 2 & 3 & 4 & 5 & 6 \\
\hline \multirow{2}{*}{\begin{tabular}{c} 
Candida glabrata \\
\cline { 2 - 8 }
\end{tabular}} & & & & & & \\
\hline
\end{tabular}

Tests were also carried out with other extracts as follows in table below where antimicrobial potential was found in plant ethanolic extracts of 3 and 5 species, for Klebsiella oxytoca, Staphylococcus epidermidis, Acinetobacter haemolyticus organisms (Figure 1).

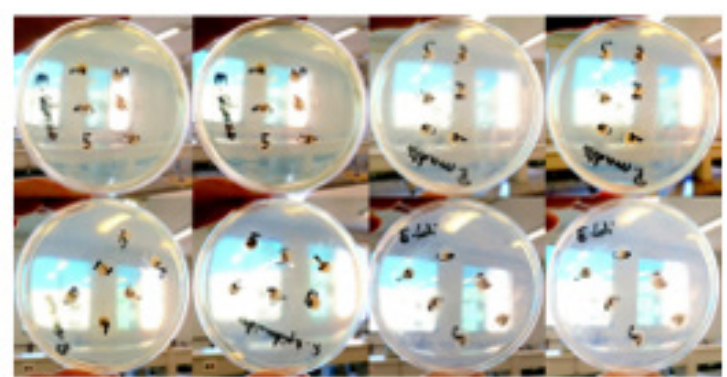

Figure 1: Ilusltraction of disc-diffusion test results in agarnutrient showing inhibition halos of plants species extracts against Staphylococcus aureus ATCC 25923; Staphylococcus epidermidis; Proteus mirabilis; Enterobacter cloacae eEscherichia colibacteria.

Figure 1 illustrates the microbial growth inhibition results by disc technique diffusion, in front of plant extracts tested. Figure 2 shows, in turn, details of growth inhibition halo formation of bacterium S. epidermidis around the disc soaked with the solution containing the foliar extracts diluted in ethanolic solvent. In relation to halos' rays observed diameter, those formed with leaf extract (P. alata Dryander) were that presented the largest dimension, with emphasis on ethanolic extract (Figure 1\&2). 


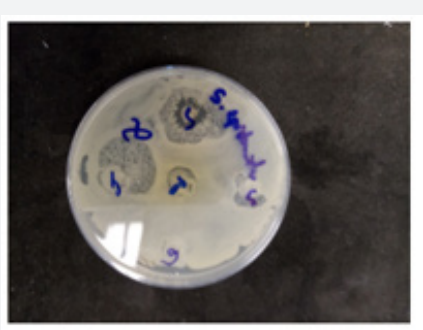

Figure 2: Illustration of Petri dish inoculated with bacterium Staphylococcus epidermidis illustrating the inhibition halos formation around some of paper discs (2.3 and 4) soaked with ethanolic solution of leaf extracts.

\section{Discussion}

The results obtained point to the presence of different plant components extracted in leaf extracts, especially secondary metabolites of a diverse nature, which would justify the differences in observed responses in relation to the various Microorganisms. In addition, the use of a polar solvent, water, compared to ethanol, more apolar, leads to the extraction of plant components with different degrees of polarities and different biological properties, such as anti-inflammatory, antioxidant, analgesic or Antimicrobial. Active compounds found in several plants demonstrate antiseptic action, such as Thymol and Carvacrol, Eugenol and Isoeugenol and Terpinenol-4. In some cases, the terpene of the essences, which are water soluble, have higher antibacterial power than others (Knobloch et al., 1989). Phenolic compounds, alkaloids, terpenes and sterols are considered the main family of secondary metabolites (Fumagali et al., 2008). Tannins are responsible for the astringency of many fruits and plant products, acting as antioxidant, antiseptic, cicatrizing and Vasoconstrictor (Pereira, Cardoso, 2012). Flavonoids have many biological effects such as antioxidant, anti-inflammatory and antitumoral activity, power to reduce permeability and capillary fragility and inhibition of platelet aggregation [9]. Another characteristic is its antibiotic activity, probably related to the ability to form complexes with soluble and extracellular proteins and with the walls of bacterial cells [8].

In the studies by Truiti [16], the antibacterial property of C. nutansraised hyposteses that justify its popular use in the treatment of wounds contaminated by bacterial infections (Gram positive bacteria), being detected that the pure compound that Antibacterial activity was identified as 7-O-B-D-Glucopiranosil-Nutanocumarina. The Oils essences also have a great value in the food and cosmetics industry, aiming its antiseptic and antimicrobial properties (Bakkali et al., 2008). In studies carried out with extracts from the root of C. Nutans, the bacterium S. aureus was considered susceptible and the bacteria E. coli and P. Aeruginosa were considered resistant to that extract [16]. Two important groups for the pharmacological area are the terpenoids and the flavonoids, the first are part of a group of secondary metabolites, characteristic of essential oils, being their use based on their antimicrobial properties, very Used by the pharmaceutical industries. The flavonoids belong to numerous classes of chemical substances in a natural way, having several pharmacological activities acting in the biological system, favoring human health with its antioxidant and antimicrobial actions [12]. In our study it was observed that the leaf extracts of C. Nutans were effective in inhibiting the growth of P. mirabilis, E. coli and S. aureus isolates. These results are very promising in view of their action on Gram-negative and Gram-positive bacteria (S. aureus), having this last great importance in public health, especially due to the frequent association of this species with nosocomial infections. It is in the execution phase to perform phytochemical tests for the evaluation of secondary metabolites present in the crude extracts of that specimen to subsequently start the execution of the minimum inhibitory concentration (MIC) tests and Minimum bactericidal concentration (CBM), which will allow for more precise conclusions and associations between the secondary metabolites found and the antimicrobial effects observed.

Regarding the genus Passiflora, phytochemical assays previously performed with the hydroalcoholic extracts of the aerial parts (leaves, stems, epicarp, pulp and seeds) established that Passiflora Cincinnata has the following classes of metabolites Secondary: Condensate tannins, flobabenic, Flavones, Flavononois, Flavonois, Xantonas, Chalcones, Aurones, Flavanones, Leucoanthocyanidine, catechins and alkaloids. These, because they are phytoconstituents derived from the secondary metabolism of vegetables, which almost always act in defense of it against pathogens, can present interesting biological activities. Biological assays using isolated combinations reveal that the flavonoids exhibit a great action on biological systems demonstrating antimicrobial, antiviral, antiulcerogenic, cytotoxic, anticancer, antioxidant, Antihepatotoxic, antihypertensive, hypolipidemic, anti-inflammatory and antiplatelet (Djahanguiri et al. 1969). The activity demonstrated in the in vitro assays performed with the hydroalcoholic extracts of P. Cincinnata evidences a probable action of phenolic compounds present in all parts, confirming the antimicrobial activity attributed to this class of Secondary metabolites. The Association of natural products to antibiotics can exert direct activity against many bacterial species, modulating or even increasing the activity of a specific antibiotic, reversing the natural resistance of bacteria. The potentialization of the activity or the reversal of antimicrobial resistance allows the classification of these compounds as modifiers of the antibiotic activity. The use of extracts becomes interesting because they present low possibility of microorganisms acquire resistance to their action, since they are complex mixtures, which hinders the microbial adaptability [17]. In our study, the growth inhibition of S. aureus and S. Epidermidis was observed in relation to aqueous extracts of Passiflora alata Dyander, demonstrating interesting results from the scientific point of view with few reports associated with the effects of those extracts on S. Epidermidis. As previously described, studies on the phytochemical composition of these extracts are executing in order to elucitake the secondary compounds present.

A. Absinthium L. (Asteraceae), commonly known as "Absinthe", is a plant traditionally used as an antihelmintic, antiseptic, antispasmodic, for the treatment of cancer, bacillary dysentery and neurodegenerative diseases. Its essential oil has antimicrobial, 
antiparasitic, insecticide and herbicial properties [18]. Studies developed by Sandra [16] showed that leaves of A. Absinthium showed poor antimicrobial activity against Staphylococcus aureus (7 mm halo), Staphylococcus Epidermidis (7 mm halo) and Enterococcus faecalis (7 mm Halo), Previous studies [19] revealed a potential activity of a. Absinthium versus S. Aureuscorroborating the results obtained in this study in which the growth inhibition of S. aureus was observed both for the ethanolic extract and for the aqueous extract. It is important to emphasize that extracts of A. Absinthiumobtained in this work demonstrated antimicrobial activity for most of the microbial isolates evaluated, except P. Mirabilis and E. Cloacae, demonstrating a broad spectrum of performance and, thus, large Pharmacologic potential.

With regard to T. Avellanedae, popularly known as Purple ipê, the bioactive compound Lapachol, I described for the first time in 1882 by Paternò [20] was already extracted. In popular use, it has produced evident results in the treatment of diabetes and gastric ulcers, besides being used as analgesic, anti-inflammatory and even as anti-mutagênico. It has also been used in hospitals, in the form of fluid extract and powder or ointment [21]. More recent studies have demonstrated the antimicrobial potential of T. Alba, whose ethanolic extract obtained from its flowers demonstrated bactericidal action against S. Epidermidis, while the ethanolic extract of the leaf was moderately active with effect Bacteriostatic on S. Epidermidis and S. aureus [14].

Sandra (2013) observed that the bark of T. Avellanedae showed a very significant activity within the established criteria against the microorganism S. Epidermidis, with an average of $10 \mathrm{~mm}$ inhibitory halo, and, against S. aureus, E. Faecallis and B. Cereus presented a little activity Significant. T. Avellanedae bark showed significant antimicrobial activity against Staphylococcus aureus (11 $\mathrm{mm}$ halo), B. Cereus (10 mm halo), S. Epidermidis (10 mm halo) and E. Faecalis (11 mm halo), although there are reports of studies about its activity against Helicobacter pylori (Saad et al, 2009), the analysis of the antimicrobial activity performed shows that the results obtained are quite promising for the continuation of the studies Antimicrobial activity against the microorganisms analyzed. In our study, we observed expressive antimicrobial activity of leaf extracts of T. Avellanedaein front of S. aureus, S. Epidermidis and E. coli, demonstrating also a broad spectrum of action whose biological components with antimicrobial action are Studies of new antimicrobial drugs.

The plant species S. Cordifolia is native to tropical America but is widespread in several regions of tropical and subtropical climate of the world. It is used in folk medicine for the treatment of Stomatitis, asthmatic bronchitis and nasal congestion. The antiinflammatory and analgesic effects were tested and confirmed in the aqueous extract of the plant, proving its popular use for that purpose [8]. In the microscopy of the white mauve powder, fragments of several fibers were detected. In the phytochemical prospecting of the white mauve observed the presence of alkaloids, phenols and saponins. The polyphenols content was $0.84 \%$ and the foam index was $100 \%$. In phytochemical analysis of Leaves of S. Cordifolia the presence of sympathoomimetic amines, ephedrine and pseudoephedrine, a potent vasoconstrictor, called Vasocinone [22] was detected. There are few reports in the literature focused on the evaluation of antimicrobial effects of leaf extracts of $\mathrm{S}$. Cordifolia, and the antimicrobial effect of extracts of that species in the present study was observed in comparison with all microbial isolates tested, Involving in this case the two extractors used, demonstrating a great antimicrobial potential of the components of their foliar extract being in execution phytochemical studies in the sense of eluciding them demonstrate their relationship with the results raised.

Regarding the gender AIDS, in Waldilleny Studies (2010) It was observed that the ethanolic extract of S. Santaremnensis (SSanEtOH) and Copaifera luetzelburgii (Cl-EtOH), it can be concluded that these species have anti-edematogênica activity evidenced in the models of ear and paw edema. Within this perspective, there is the need for studies in order to determine the possible mechanisms of action of the extracts studied. Regarding the antimicrobial activity of extracts of that genus, there are few studies evaluating its inhibitory effects. In the present study we detected inhibitory action of leaf extracts of S. Cordifolia against S. aureus, S. Epidermidis and E. coli, in different degrees, with emphasis on the ethanolic extracts produced. This antimicrobial property represents poorly exploited property and can be aggregated the biological activities already elucidated for extracts of that genus.

The genus Bidens is composed of about 240 species distributed in the tropical and subtropical zone of the globe. In Brazil, this species is native to Rio Grande do Sul and occurs in the physiographic regions of Campos de Cima da Serra, Middle Plateau, Central Depression, Serra do Sudeste and Campanha; Inhabiting fields, forest margins, roadside ruderal, wasteland and agricultural areas [23]. Bidens spp. It is used in traditional medicine for the treatment of hepatitis, jaundice, fever, throat affections and coughs [12]. In this sense, several studies have confirmed the medicinal potential of Bidens spp. with anti-inflammatory actions [7] Analgesics [18], Anti-hiperglicêmica and antioxidant [3]. However, the biological activities of B. Subalternans have not been evaluated and the traditional uses of this species still need to be confirmed. Species of the genus Bidens, in addition to the traditional effects, have an important antimicrobial action. Deba et al. (2008) showed that the essential oils of leaves and flowers of Bidens pilosa have a significant activity against the Gram-positive bacteria Micrococcus flavus, Bacillus subtilis, Bacillus cereus and Bacillus pumilus, as well as against the rods Gram-negative E. coli and Pseudomonas ovalis. In addition, the extracts of leaves [24], Deba et al, 2008). In our study we obtained a significant result of inhibition of the growth of the bacterium E. Cloacae, both for the ethanolic extract and for the aqueous extract. Considering the importance of this bacterial species as an opportunistic and also nosocomial pathogen, associated with the absence of reports in the literature on the effects of leaf extracts of Bidens against that microbial 
species [25-30], this result aroused Interest in deepening studies in relation to the compounds eventually involved in that response. The phytochemical analysis of aqueous and ethanolic extracts obtained from specimens of Bidens SP is underway [31-35].

\section{Conclusion}

Based on the results obtained, it is possible to conclude the great antimicrobial potential of Cerrado and Mata Atlantica extracts from the region of Pitangui MG, Brazil. Extracts of B. forficata, A. absinthium, S. cordifoliae, T. avellanedae, B. retusa and B. dracunculifolia showed interesting antibacterial and antifungal effects against several microbial species of medical importance. Complementary experiments are necessary to elucidate the constituents of those extracts responsible for the important results observed.

\section{Acknowledgement}

None.

\section{Conflicts of Interest}

No conflicts of interest.

\section{References}

1. Baggio AA, Medrado MJS (2003) Agroforestry Systems and, Biodiversity (2003) In: Seminar [On] Agroforestry Systems and Sustainable Development, Campo Grande. Anais Campo Grande: Embrapa Gado de Corte.

2. Schulz V, Hansel R, Tyler VE (2002) Rational Phytotherapy - A Guide to Phytotherapy for Health Sciences. 4th edition.

3. Dutra RC, Dutra MM, Campos BC, Adair RS, Santosd JB et al. (2016) Medicinal plants in Brazil: Pharmacological studies, drug discovery, challenges and perspectives. Pharmacological Research 112: 4-29.

4. Santoro DS, Ahrensa K, Vesnya R, Navarrob C, Gattoc H, et al. (2017) Evaluation of the in vitro effect of Boldo and Meadowsweet plant extracts on the expression of antimicrobial peptides and inflammatory markers in canine keratinocytes. Research in Veterinary Science 115: 255-262.

5. Nunan EA (1985) Estudo da atividade antimicrobiana de extrato de folha de Aristolochiagigantea Mart E Zucc. Revista de Farmácia e Bioquímica Belo Horizonte 6(1): 33-40.

6. Murray PR (1995) Laboratory Procedures for Epidemiologic Analysis. In: Manual of Clinical Microbiology 6 ed Washington: ASM Press.

7. Verhoef J, Beaujeand, Blok H, Baars A, Meyler A, et al. (1999) A Ducht approach to methicillin-resistant Staphylococcus aureus. European Journal of Clinical Microbiol \& Infectious Diseases 18(7): 461-466.

8. Nascimento GGF (2000) Antibacterial activity of plant extracts and phytochemical sonantibiotic-resistant bacteria. Brazilian Journal of Microbiology, 31(4): 247-56.

9. Simões CMO (2001) Pharmacognosy: from plant to drug, 2 ed Porto Alegre: Publisher of UFRGS 821.

10. (2005) Who - World Health Organization. Traditional Medicine Strategy 2002-2005. Geneva: WHO 61.

11. Queiroz MS, (1996) The mechanistic paradigm of modern Western medicine: an ontropological perspective. Revista de Saúde Pública 20: 309-311.

12. Simões CMO, Mentz LA, Schenkel EP, Nicolau M, Bettega JR (1998) Plants of the Popular Medicine of Rio Grande do Sul. 5. ed.Porto Alegre: UFRGS Publishing House 1(150).

13. Akerele 0 (1993) Summary of WHO guidelines for assessment of herbal medicines. Herbal Gram 28: 13-19.
Almeida SP, Proença CEB, Sano SM Ribeiro JF (1998) Closed: Useful vegetable species. Planaltina, Embrapa-CPAC.

14. Guarim Neto G, Morais RGD (2003) Medicinal resources of Cerrado species of Mato Grosso: a bibliographic study. Acta Botanica Brasilica 17: 561-584.

15. Dignani MC, Anaissie E (2003) Medical Mycology. Led Philadelphia: 195239.

16. Mendonça Filho RFW, Menezes FS (2003) Study of the use of medicinal plants by the population of Ilha Grande RJ Rev Bras Farmacogn 13(S): 55-58.

17. Meyers N (1983) Tropical moist forests; over-exploited and underutilized. Forest Ecology and Management 6: 59-79.

18. Bona, Eliana Almeida Mira De (2014) Comparison of methods for evaluation of antimicrobial activity and determination of minimum inhibitory concentration (cim) of aqueous and ethanolic vegetable extracts. See Pharmacology Scientific Article. Sao Paulo.

19. Coutinho HDM, Coast JGM, Siqueira Jp, Lima EO (2009) Effect of Momordica charantia L. in theresistance to aminoglycosides in ethicilinresistant Staphylococcus aureus. Comp Immunol Microbiol Infect Dis 33(6): 467-71.

20. Pozetti GL, Pizsolitto AC, Mancini B, Loshchagin E Machado AC (1972) Determination of the antimicrobial activity of Brazilian plants. Journal of the Faculty of Pharmacy and Dentistry Araraquara 6: 29-33.

21. Carlini EA, Rodrigues E, Mendes FR, Tabach R, Gianfratti B (2006) Treatment of drug dependence with Brazilian herbal medicines. Rev Bras Pharmaogn 16: 690-695.

22. (1978) Oms Organização Mundial da Saúde. Declaração De Alma-Ata. In: I Conferência Internacional Sobre Cuidados Primários De Saúde. AlmaAta: OMS 3.

23. Pazhani GP, Sarkar B, Ramamurthy T, Bhattacharya SK, Takeda Y, et al. (2004) Clonal multidrug-resistant Shigella dysenteriae Type 1 strains associated with epidemic and sporadic dysenteries in Eastern India. Antimicrobial Agents Chemotherapy 48(2): 681-684.

24. Mendonça R, Felfili JM, Walter BMT, Silva Júnior MC, Rezende AV et al. (1998) Cerrado vascular flora. 287-556. In: Sano S, Almeida S (eds).

25. Araújo JCLV, Lima EO, Cabralos BSO, Freire KRL, Souza EL (2004) Antimicrobial action of essential oils on microorganisms potentially causing opportunistic infections. Rev Patol Trop 33: 55-64.

26. Bauer AW, Kirby, WMM, Sherris JC, Turck M (1966) Antibiotic susceptibility testing by a standardized single disc method. Am J Clin Pathol USA 45: 493-496.

27. Brazil, Ministry of Health. Use of herbal and phytotherapeutic plants rises $161 \%$.

28. Guimarães KG (2007) Antimicrobial Activity of Occurring Species in Serra do Cipó and Xyrispterygoblephara Kunth Photochemical Study. $141 \mathrm{f}$ Dissertation presented to the Graduate Course in Pharmaceutical Sciences of the Faculty of Pharmacy of the Federal University of Minas Gerais, as a partial requirement to obtain a master's degree in Pharmaceutical Sciences. Belo Horizonte.

29. Hughes C, Muller D, Hacher J, Goebel W (1982) Genetics and pathogenic role of Escherichia coli haemolysin. Toxicon 20(1): 247-52.

30. Koehn FE, Carter GT (2005) "The Evolving Role of Natural Products in Drug Discovery." Nature Reviews Drug Discovery 4(3): 206-220.

31. Mengue SS, Mentz LA, Schenkel EP Use of medicinal plants in pregnancy. Rev Bras Farmaogn 11: 21-35.

32. Moreno S, Scheyer T, Romano CS, Vojnov AA (2006) Antioxidant and antimicrobial activities of rosemary extracts linked to their polyphenol composition. Free Radical Research, Buenos Aires 40: 223-231.

33. Mostafa AA, Mostafa AB, Abdulaziz A, Al-Askar A, Khalid S, et al. (2017) Antimicrobial activity of some plant extracts against bacterial strains causing food poisoning diseases. Saudi Journal of Biological Sciences 25(2): 361-366. 
34. Nostro A, Blanco AR, Cannatelli MA, Enea V, Flamini G, et al. (2004) Susceptibility of methicillin-resistant staphylococcito orégano essential oil carvacrolandthymol. FEMS Microbiology Letter 230(2): 191-195.
35. Palleroni NJ (1993) Pseudomonas, classification: a new case history in the taxonomy of Gram-negative bacteria. Antonie van Leeuwenhoek, 64(3-4): 231-251. 